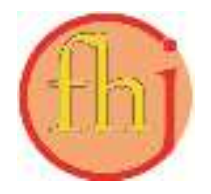

Faletehan Health Journal, 8 (3) (2021) 238-243

www. journal.Ippm-stikesfa.ac.id/ojs/index.php/FHJ

ISSN 2088-673X | e-ISSN 2597-8667

\title{
Hubungan Pengetahuan dengan Sikap Perawat tentang Triage di IGD Dimasa Pandemi Covid-19
}

\author{
Galih Satria ${ }^{1}$, Donal Nababan ${ }^{1}$, Rumondang Gultom ${ }^{1}$, Siska Evi Martina ${ }^{1 *}$ \\ ${ }^{1}$ Universitas Sari Mutiara Indonesia \\ *Correspondence Author: siskaevi21@gmail.com
}

\begin{abstract}
Abstrak
Banyaknya pasien yang datang di IGD membuat perawat harus memilah pasien dengan cepat dan tepat sesuai prioritas. Hal tersebut memerlukan pengetahuan dan sikap dalam hal pemisahan jenis dan kegawatan pasien dalam triase, sehingga penanganan pasien bisa lebih optimal dan terarah. Penelitian ini bertujuan untuk mengetahui hubungan antara pengetahuan dan sikap perawat tentang triage. Penelitian ini menggunakan metode penelitian korelasi dengan pendekatan cross-sectional. Penelitian dilakukan di IGD RSUD Dr. H Kumpulan Pane Kota Tebing Tinggi, RSUD Rantau Prapat, dan RSUD Tuan Rondahaim Simalungun dari bulan Januari sampai Agustus 2020. Sampel dalam penelitian ini sebanyak 46 perawat yang bertugas di IGD RSUD Dr. H Kumpulan Pane Kota Tebing Tinggi, RSUD Rantau Prapat, dan RSUD Tuan Rondahaim Simalungun yang diambil secara total sampling. Instrumen penelitian menggunakan kuesioner. Analisis data menggunakan korelasi spearman rank pada taraf kepercayaan 95\%. Hasil analisis univariat menunjukkan mayoritas perawat memiliki pengetahuan tentang triase yang cukup (48\%) dan mayoritas perawat bersikap positif (77\%). Hasil analisis statistik spearman rank memperoleh nilai koefisien korelasi spearman sebesar 0,753 dengan $\rho$-value $0,000<0,05$, sehingga Ha diterima. Kesimpulan dalam penelitian ini terdapat hubungan antara pengetahuan dan sikap perawat tentang triase di RSUD Dr. H Kumpulan Pane Kota Tebing Tinggi, RSUD Rantau Prapat, dan RSUD Tuan Rondahaim Simalungun.
\end{abstract}

Kata Kunci: Pengetahuan Perawat, Sikap Perawat, Triase, IGD, Pandemi Covid-19

\section{Correlation Between Nurses' Knowledge and Attitude of Triage in Ers in Covid-19 Pandemic Era}

\begin{abstract}
The number of patients who come to the emergency department makes nurses have to sort patients quickly and precisely according to priority. It requires knowledge and attitude in terms of segregation of patient type and emergency in triage, so that patient care can be more optimal and directed. This study aimed to find out the correlation between nurses' knowledge and attitudes of triage. Theresearch used a correlation research method with a cross-sectional approach. The study was carried out at the emergency room of Dr. H Kumpulan Pane General Hospital in Tebing Tinggi City, Rantau Prapat General Hospital, and Tuan Rondahaim Simalungun General Hospital from January to August 2020. The samples of this study were 46 nurses in charge at the emergency room of Dr. H Kumpulan Pane General Hospital in Tebing Tinggi City, Rantau Prapat General Hospital, and Tuan Rondahaim Simalungun General Hospital, taken by total sampling. The research instrument was a questionnaire. The data analysis used Spearman's rank correlation at the $95 \%$ confidence interval. The results of the descriptive analysis showed that majority of nurses had adequate knowledge of triage (48\%) and majority nurses had positive attitude (77\%). The results of Spearman's rank statistical analysis obtained a spearman correlation coefficient of 0.753 with $\rho$-value $0.000<0.05$; thus, Ha was accepted. In conclusion, there is a correlation between nurses' knowledge and attitude of triage at Dr. H Kumpulan Pane General Hospital in Tebing Tinggi City, Rantau Prapat General Hospital, and Tuan Rondahaim Simalungun General Hospital.
\end{abstract} Keywords: Nurse Knowledge, Nurse Attitude, Triage, ER, Covid-19 Pandemic 
Faletehan Health Journal, 8 (3) (2021) 238-243

www. journal.Ippm-stikesfa.ac.id/ojs/index.php/FHJ

\section{Pendahuluan}

Saat ini, kekhawatiran meningkat sejalan dengan meluasnya penularan COVID-19 di beberapa bagian dunia dan kemampuan untuk menurunkan tingkat penurunan di sejumlah negara lainnya. Salah satu pelayanan yang dilakukan oleh para perawat di Instalasi Gawat Darurat di massa pandemik COVID-19 ini adalah melakukan triage. Dimana pada massa pandemik COVID-19 ini triage berfungsi untuk membagikan pasien dalam beberapa kelompok berdasarkan tingkat kegawatdaruratan pasien yang di prioritaskan dengan menilai ada tidaknya gangguan Airway (A), breathing (B), dan circulation (C) serta triage juga dilakukan untuk menilai ada tidaknya aspek tingkat virulensa pasien yang dapat dinilai dengan melihat terdapat atau tidaknya indikator-indikator EWS Screening COVID-19 (HIPGABI, 2020). Sehingga pengetahuan seorang perawat dalam menangani respon pasien di IGD sangatlah diperlukan (Aryono, 2016).

Upaya menyelamatkan pasien pasien sebanyak-banyaknya dan dalam waktu yang singkat di IGD sangat diperlukan pengetahuan dan sikap petugas kesehatan. Hal ini dikaitkan dengan pengambilan keputusan klinis agar tidak terjadi kesalahan. Pengetahuan perawat terkait ilmu yang mandasari tindakan dalam menangani pasien gawat darurat sangat penting, karena tindakan yang cepat dan akurat tergantung dari ilmu yang dikuasi oleh petugas kesehatan di IGD (Laoh \& Rako, 2014).

Tidak hanya itu, sikap perawat juga mempengaruhi seorang perawat dalam memberikan asuhan keperawatan yang salah satunya adalah dalam penerapan triage. Hal ini karena sikap merupakan aktivitas yang terintegrasi dan setiap perawat memiliki sikap yang berbeda. Melalui sikap manusia terus menerus mengadakan hubungan dengan lingkungannya. Hubungan ini dilakukan lewat inderanya, yaitu indera penglihat, pendengar, peraraba, perasa, dan pencium. Oleh karena itu seseorang bisa saja memiliki sikap yang berbeda walaupun objeknya sama. Hal tersebut dimungkinkan karena adanya perbedaan dalam hal sistem nilai dan ciri kepribadian individu yang bersangkutan (Afaya, Azongo, \& Yakon, 2017).

Maka dari itu, di Instalasi Gawat Darurat (IGD) pengetahuan dan sikap perawat sangat dibutuhkan, perawat harus mampu memprioritaskan perawatan pasien atas dasar pengambilan keputusan klinis dimana ketrampilan penting bagi perawat dalam penilaian awal, perawat harus mampu memprioritaskan perawatan pasien atas dasar pengambilan keputusan yang tepat. Untuk mendukung hal tersebut diperlukan pengetahuan, sikap dan ketrampilan khusus dalam hal pemisahan jenis dan kegawatan pasien dalam triage, sehingga dalam penanganan pasien bisa lebih optimal dan terarah. Adapun untuk meningkatkan pengetahuan, sikap dan keterampilan perawat tersebut, perawat dapat mengikuti pelatihan BTCLS (Basic Training Cardiac Life Support) atau PPGD (Pertolongan Pertama Gawat Darurat) (Sari, 2017).

Hasil penelitian yang dilakukan oleh Farokhnia dan Gorransson (2015) mengenai "Swedish emergency department triage and interventions for improved patient flows: a national update" melaporkan mengenai peningkatan penerapan kualitas triage pada emergency department di Sweden dari tahun 2010 (79\%) ke tahun 2015 (98\%). Sedangkan penerapan triage di Indonesia dengan presentase $76 \%$ sampai dengan $89 \%$ dari 1.863 rumah sakit yang ada di Indonesia. Data yang didapat pada tahun 2014 sampai 2017 mengalami peningkatan yang signifikan dari tahun ke tahun. Hal ini disebabkan karena sudah banyak perawat yang diikutkan dalam pelatihan penanganankegawatdaruratan berdasarkan sistem triage sehingga pengetahuan dan sikat perawat terhadap sistem triase di IGD pun semangkin membaik (Riskesdas, 2018). Sedangkan di Provinsi Sumatera Utara sendiri, penerapan triase mengalami kenaikan dari $62,5 \%$ menjadi $80 \%$ dalam kurun waktu 20142016 dari 62 rumah sakit umum daerah yang ada di Provinsi Sumatera Utara (Dinas Kesehatan Provinsi Sumatera Utara, 2018).

Berdasarkan data dari Medical Record, kunjungan pasien pada pelayanan Instalasi Gawat Darurat RSUD Dr. H. Kumpulan Pane selama bulan Januari 2019 - bulan Januari 2020 adalah 15.112 pasien. Rata-rata jumlah pasien setiap hari yang masuk mencapai 41 pasien (Rekam Medis RSUD Dr. H. Kumpulan Pane, 2020). Sedangkan jumlah tenaga perawat di IGD berjumlah 19 orang yang terdiri dari S1 Keperawatan 2 orang, dan D3 Keperawatan 17 orang. Sedangkan kunjungan pasien pada 
pelayanan Instalasi Gawat Darurat RSUD Rantau Prapat selama bulan Januari 2019 - bulan Januari 2020 adalah 16.438 pasien. Rata-rata jumlah pasien setiap hari yang masuk mencapai 46 pasien (Rekam Medis RSUD Rantau Prapat, 2020). Sedangkan jumlah tenaga perawat di IGD berjumlah 20 orang yang terdiri dari S1 Keperawatan 3 orang, D4 Keperawatan 1 orang dan D3 Keperawatan 16 orang. Sementara itu kunjungan pasien pada pelayanan Instalasi Gawat Darurat di RSUD Tuan Rondahaim Simalungun sendiri selama bulan Januari 2019 bulan Januari 2020 adalah 12.654 pasien. Ratarata jumlah pasien setiap hari yang masuk mencapai 35 pasien (Rekam Medis RSUD Tuan Rondahaim, 2020). Sedangkan jumlah tenaga perawat di IGD berjumlah 16 orang yang terdiri dari S1 Keperawatan 4 orang, dan D3 Keperawatan 12 orang.

Hasil observasi awal ditemukan ada beberapa perawat IGD yang bertugas di RSUD Kumpulan Pane Kota Tebing Tinggi, RSUD Rantau Prapat, RSUD Tuan Rondahaim Simalungun melakukan kesalahan dalam melakukan proses triage dimasa pandemik covid-19 ini, dimana mereka tidak menggunakan protab alur prosedur triage terbaru yang disesuaikan dengan massa covid-19 tetapi masih menggunakan alur triage yang lama. Saat dilakukan wawancara, sebagian perawat masih belum mengetahui apa perbedaan dan bagaimana proses triage pada massa pandemik covid-19 ini. Bahkan ada beberapa perawat tidak melakukan triage oleh karena alasan pasien bisa berjalan dan tidak memperlihatkan gejala yang mengarah kepada kasus covid-19 sehingga disimpulkan bahwa pasien berada pada kondisi tidak gawat dan tidak darurat. Hal ini mungkin terjadi karena masih minimnya perawat yang sudah mengikuti pelatihan BTCLS (Basic Training Cardiac Life Support). Dimana, dari keseluruhan perawat yang berjumlah 53 perawat yang bertugas di IGD RSUD Dr. H. Kumpulan Pane Kota Tebing Tinggi, RSUD Rantau Prapat dan RSUD Tuan Rondahaim Simalungun hanya 20 perawat yang sudah mengikuti pelatihan BTCLS (Basic Training Cardiac Life Support).

Berdasarkan uraian latar belakang tersebut, maka peneliti tertarik untuk melakukan penelitian dengan judul "Hubungan Antara Pengetahuan Dengan Sikap Perawat IGD Tentang Triage Di Instalasi Gawat Darurat
RSUD Dr. H. Kumpulan Pane Kota Tebing Tinggi, RSUD Rantau Prapat, RSUD Tuan Rondahaim Simalungun Pada Massa Pandemi Covid-19".

\section{Metodologi Penelitian}

Jenis penelitian yang digunakan adalah observasional dengan metode korekasi melalui pendekatan cross sectional, yang bertujuan untuk menganalisis Hubungan Antara Pengetahuan Dengan Sikap Perawat IGD Tentang Triage Di Instalasi Gawat Darurat RSUD Dr. H. Kumpulan Pane Kota Tebing Tinggi, RSUD Rantau Prapat, RSUD Tuan Rondahaim Simalungun Pada Massa Pandemi covid19. Sampeldalam penelitian ini adalah 15 perawat yang bertugas di ruang IGD RSUD Dr. H. Kumpulan Pane Kota Tebing Tinggi, 17 perawat RSUD Rantau Prapat, 14 perawat RSUD Tuan Rondahaim Simalungun Provinsi Sumatera Utara, sehingga total sampel pada penlitian ini berjumlah 46 perawat Tehnik pengambilan sampel dalam penelitian ini adalah teknik Purposive Sampling yaitu teknik pengambilan sampel dengan cara memilih sampel diantara populasi yang sesuai dengan yang dikehendaki peneliti, sehingga sampel tersebut dapat mewakili karakteristik populasi yang telah dikenal sebelumnya. Pemilihan sampel penelitian ini berdasarkan kriteria inklusi dan eksklusi yang telah ditetapkan oleh peneliti. Data penelitian berdistribusi tidak normal sehingga dianalisis menggunakan uji Spearman Rank dengan nilai $\mathrm{p}<$ 0,05 .

\section{Hasil dan Pembahasan Analisa Univariat}

Analisa univariat digunakan untuk melihat distribusi frekuensi dari setiap variabel yang diteliti yang disajikan dalam bentuk tabel dan grafik. Variabel yang dianalisa secara univariat dalam penelitian ini meliputi karakteristik responden yang berupa jenis kelamin, usia, lama bekreja, Sudah atau tidaknya mengikuti pelatihan BTCLS, pengetahuan dan sikap perawat tentang triage.

Tabel 1: Distribusi Responden Berdasarkan Jenis Kelamin Perawat IGD Di RSUD Dr. H. Kumpulan Pane Tebing Tinggi, RSUD Rantauprapat, RSUD Tuan Rodahaim Simalungun 
Faletehan Health Journal, 8 (3) (2021) 238-243

www. journal.Ippm-stikesfa.ac.id/ojs/index.php/FHJ

ISSN 2088-673X | 2597-8667

\begin{tabular}{lcc}
\hline \multicolumn{1}{c}{ Variabel } & f & \% \\
\hline Pria & 29 & 63 \\
\hline Wanita & 17 & 37 \\
\hline Total & $\mathbf{4 6}$ & $\mathbf{1 0 0}$ \\
\hline
\end{tabular}

yang belum mengerti dan memahami beberapa indikator yang terdapat dalam kuesioner.

Tabel 4: Distribusi Responden Berdasarkan Sikap Perawat IGD Tentang Triage Di RSUD Dr. H. Kumpulan Pane Tebing Tinggi, RSUD Rantauprapat, RSUD Tuan Rodahaim

Perawat IGD Di RSUD Dr. H. Kumpulan Pane Tebing Tinggi, RSUD Rantauprapat, RSUD Tuan Rodahaim Simalungun

\begin{tabular}{|c|c|c|}
\hline Usia & f & $\%$ \\
\hline $20-30$ & 22 & 48 \\
\hline $31-40$ & 16 & 35 \\
\hline $41-50$ & 8 & 17 \\
\hline Total & 46 & 100 \\
\hline
\end{tabular}

Distribusi karakteristik responden berdasarkan usia diketahui mayoritas perawat IGD adalah berusia 20-30 tahun sebanyak 22 orang $(48 \%)$.

Tabel 3: Distribusi Responden Berdasarkan Pengetahuan Perawat Perawat IGD Tentang Triage Di RSUD Dr. H. Kumpulan Pane Tebing Tinggi, RSUD Rantauprapat, RSUD Tuan Rodahaim Simalungun

\begin{tabular}{lcc}
\hline $\begin{array}{c}\text { Pengetahuan Perawat } \\
\text { tentang Triage }\end{array}$ & f & $\boldsymbol{\%}$ \\
\hline Baik & 16 & 35 \\
\hline Cukup & 22 & 48 \\
\hline Buruk & 8 & 17 \\
\hline Total & $\mathbf{4 6}$ & $\mathbf{1 0 0}$ \\
\hline
\end{tabular}

Distribusi pengetahuan perawat tentang triage diketahui mayoritas perawat IGD mempunyai pengetahuan cukup tentang triage sebanyak 22 orang (48\%). Tingkat pengetahuan yang masih cukup disebabkan karena masih didapat responden

Tabel 5: Hasil Analisis Bivariat Hubungan Pengetahuan dengan Sikap Perawat IGD Tentang Triage Di RSUD Dr. H. Kumpulan Pane Tebing Tinggi, RSUD Rantauprapat, RSUD Tuan Rodahaim Simalungun

\begin{tabular}{|c|c|c|c|c|c|c|c|c|}
\hline \multirow{3}{*}{ Pengetahuan } & \multicolumn{4}{|c|}{ Sikap } & \multirow{2}{*}{\multicolumn{2}{|c|}{ Total }} & \multirow{3}{*}{$\rho$} & \multirow{3}{*}{$\mathbf{P}$} \\
\hline & \multicolumn{2}{|c|}{ Positif } & \multicolumn{2}{|c|}{ Negatif } & & & & \\
\hline & $\mathbf{F}$ & $\%$ & $\mathbf{F}$ & $\%$ & $\mathbf{F}$ & $\%$ & & \\
\hline Baik & 14 & $30,4 \%$ & 2 & $4,4 \%$ & 16 & $34,8 \%$ & \multirow{4}{*}{0,753} & \multirow{4}{*}{0,000} \\
\hline Cukup & 16 & $34,8 \%$ & 6 & $13,0 \%$ & 22 & $47,7 \%$ & & \\
\hline Kurang & 1 & $2,2 \%$ & 7 & $15,2 \%$ & 8 & $17,3 \%$ & & \\
\hline Total & 31 & $67,4 \%$ & 15 & $32,6 \%$ & 46 & $100 \%$ & & \\
\hline
\end{tabular}


Berdasarkan analisis bivariat menggunakan spearman rank menghasilkan nilai koefisien spearman rank sebesar 0,753 dengan nilai signifikansi sebesar $0,000<0,05$. Hal ini berarti dan Ha diterima yang artinya ada hubungan antara aengetahuan dengan sikap perawat IGD tentang triage di instalasi gawat darurat RSUD Dr. H. Kumpulan Pane Kota Tebing Tinggi, RSUD Rantau Prapat, RSUD Tuan Rondahaim Simalungun pada massa pandemi covid-19.

Berdasarkan hasil analisis bivariat untuk mengetahui ada tidaknya hubungan antara pengetahuan dan sikap perawat tentang triage dengan menggunakan teknik analisis Spearman Rank menunjukkan hasil bahwa nilai signifikansi ( $p$ value) sebesar $0,000<0,05$. Hal ini berarti Ha diterima yang artinya ada hubungan antara pengetahuan dengan sikap perawat IGD tentang triage di instalasi gawat darurat RSUD Dr. H. Kumpulan Pane Kota Tebing Tinggi, RSUD Rantau Prapat, RSUD Tuan Rondahaim Simalungun pada massa pandemi covid-19. Didukung dari hasil analisis tabulasi silang menunjukkan bahwa perawat dengan pengetahuan yang cukup mempunyai sikap yang positif dalam pelaksanaan triage di IGD. Perawat yang mempunyai pengetahuan yang baik akan cenderung mempunyai sikap yang positif pula dalam pelaksanaan triage di IGD terhadap pasien. Namun perawat yang mempunyai pengetahuan yang kurang tentang triage maka mereka juga akan mempunyai sikap yang Negatif dalam pelaksanaan triage di IGD terhadap pasien. Hasil penelitian tersebut menunjukkan bahwa semakin baik tingkat pengetahuan maka akan semakin baik sikap perawat dalam pelaksanaan triage. Pengetahuan merupakan aspek penting yang harus dimiliki seorang perawat karena dapat memengaruhi keterampilan tertentu. Pengetahuan yang tinggi seseorang akan mampu melaksanakan semua tugas secara efektif dan efisien, sehingga kinerja semakin membaik. Seseorang dengan tingkat pengetahuan yang tinggi dapat mematuhi setiap tindakan yang dilakukannya.

Pada hasil penelitian ini didapat mayoritas pengetahuan perawat masih dalam kategori cukup. Hal ini dapat dijelaskan dengan teori bahwasanya pengetahuan seseorang diperoleh secara internal dan eksternal. Dimana pengetahuan yang diperoleh dari internal adalah pengetahuan yang berasal dari diri sendiri yang biasanya didapat dari pengalaman dilapangan. Sedangkan pengetahuan yang diperoleh dari eksternasl adalah pengetahuan yang didapat dari orang lain seperti hasil pendidikan dan pelatihan. Maka dari itu hasil pengetahuan perawat tentang prosedur triage pada massa pandemic civid-19 ini mayoritas cukup dapat disebabkan karena masih barunya sistem triage di IGD menggunakan alur protab covid-19 sehingga masih sedikitnya pengalaman dalam melaksanakan prosedur triage di IGD sesuai protab covid-19 pada masa pandemic covid-19 ini dan masih sedikitnya pelatihan-pelatihan yang diberikan pihak rumah sakit mengenai Alur triage pada massa pandemic covid- 19.

Sedangkan hasil penelitian untuk aspek sikap menunjukkan bahwasanya mayoritas perawat memiliki sikap posif terhadap proses triage pada massa pandemic covid-19 ini sedangkan pengetahuannya cukup. Hal ini dapat terjadi karena bukan hanya faktor pengetahuan sajalah yang dapat mempengaruhi sikap seseorang, masih ada factor lain seperti faktor dorongan dari orang la, factor dari media massa dan factor emosional dari perawat itu sendiri. Maka dari itu bisa saja pengetahuan perawat masih dalam kategori cukup tetapi memiliki sikap tang positif terhadap prosedur triage pada massa pandemic covid-19 ini.

Hasil penelitian ini sejalan dengan hasil penelitian Martanti dkk (2015); Sari dan Sutanta (2017) menunjukkan bahwa ada hubungan antara pengetahuan dengan pelaksanaan triage di UGD. Pengetahuan triage diperlukan perawat untuk menentukan prioritas penanganan dan pengambilan keputusan yang tepat untuk pasien. Perawat harus mampu memprioritaskan perawatan pasien atas dasar pengambilan keputusan klinis dimana pengetahuan penting bagi perawat dalam penilaian awal, dan perawat harus mampu memprioritaskan perawatan pasien atas dasar pengambilan keputusan yang tepat. Untuk mendukung hal tersebut diperlukan pengetahuan, sikap, dan ketrampilan khusus dalam hal pemisahan jenis dan kegawatan pasien dalam triage, sehingga dalam penanganan pasien bisa lebih optimal dan terarah.

Begitu juga sejalan dengan hasil penelitian Sukamto dkk (2013); Santosa dkk (2015) dimana menunjukkan bahwa ada hubungan yang bermakna antara pengetahuan dengan tindakan berdasarkan labeling triase dan memiliki hubungan yang sangat kuat. Pengetahuan adalah hasil pengindraan 
Faletehan Health Journal, 8 (3) (2021) 238-243

www. journal.Ippm-stikesfa.ac.id/ojs/index.php/FHJ

ISSN 2088-673X | 2597-8667

manusia, atau hasil tahu seseorang terhadap objek melalui indra yang dimilikinya. Hal ini merupakan domain yang sangat penting untuk terbentuknya sikap bagi seseorang, bila pengambilan sikap didasari oleh pengetahuan akan lebih langgeng dari pada sikap yang tidak didasari oleh pengetahuan. Hasil penelitian menunjukkan responden dengan pengetahuan baik dapat memiliki sikap yang positif. Pengetahuan disini merupakan dasar bagi seseorang sehingga terbentuk sikap yang sesuai dengan kebutuhan, pengetahuan merupakan faktor intriksi dari dalam diri perawat yang mempengaruhi terbentuknya sikap. Pengetahuan merupakan hal penting yang harus dimiliki seorang perawat profesional agar dapat melaksanakan tugas dan tanggung jawabnya dengan baik. Secara konsep pendidikan mempengaruhi pengetahuan yang dimiliki seseorang, tetapi dalam melakukan tindakan di IGD selain pendidikan formal juga perlu ditambah dengan pelatihan yang berhubungan dengan keperawatan gawat darurat. Jadi dapat ditarik kesimpulan bahwa ada hubungan antara pengetahuan dan sikap perawat tentang triage dengan menggunakan teknik analisis Spearman Rank sebesar 0,753 dengan nilai signifikansi sebesar $0,000<0,05$. Hal ini berarti $\mathrm{Ha}$ diterima yang artinya ada hubungan antara pengetahuan dengan sikap perawat IGD tentang triage di instalasi gawat darurat RSUD Dr. H. Kumpulan Pane Kota Tebing Tinggi, RSUD Rantau Prapat, RSUD Tuan Rondahaim Simalungun pada massa pandemi covid-19.

\section{Simpulan}

Pengetahuan dan sikap perawat IGD signifikan berhubungan sehingga diharapkan dengan peningkatan pengetahuan triage perawat di IGD selama masa pandemi akan membuat sikap perawat menjadi lebih baik. Sehingga mutu pelayanan IGD Rumah Sakit dengan angka kunjungan pasien yang tinggi di masa pandemi ini akan dirasakan maksimal oleh pasien, keluarga, dan masyarakat.

\section{Referensi}

Afaya, A., Azongo, T. B., \& Yakon, V. N. (2017). Perceptions and Knowledge on Triage of Nurses Working in Emergency Departements of Hospitals in The Tamale Metropolis. Journal of Nursing and Health Science.
Aryono, D. (2016). Kegawatdaruratan dan Bencana. Jakarta: Rayyana Komunikasi Indo.

DepKes RI. (2018). Peraturan Menteri Kesehatan Republik Indonesia No. 47 Tahun 2018 Tentang Pelayanan Kegawatdaruratan. Tersedia http//www depkesgoid/resources/download/pu sdatin/profil- kesehatanindonesia/profilkesehatanindonesia-2018 pdf (Diakses tanggal 15 Mei 2020).

DinKes Provinsi Sumatera Utara. (2018). Laporan Kinerja (LK) Instansi

Pemerintah Tahun 2017. Diakses dari http://www.dinkessumutprov.go.id pada tgl 20 Mei 2020.

Farokhnia, A \& Gorransson, D . (2015). Swedish emergency department triage and interventions for improved patient flows: a national update". Artikel ECG.

Laoh, J. M., \& Rako, K. 2014. Gambaran Pengetahuan Perawat Pelaksana Dalam Penanganan Pasien Gawat Darurat Di Ruangan IGD Blu RSUP. Prof. Dr. R. D Kandou Manado, 3(September), 43-51

Martanti, R dkk. (2015). Hubungan tingkat pengetahuan dengan keterampilan petugas dalam pelaksanaan triage di instalasi gawat darurat rsud wates. 4(2):69-76.

Nursalam. (2015). Manajemen Keperawatan, Aplikasi dalam Praktik Keperawatan Profesional. Jakarta: Salemba Medika

Pradana, A.dkk. (2016). Gambaran Pengetahuan Perawat Dalam Melakukan Triage. Surakarta: STIKES Kusuma Husada.

Sari, Susanta. (2017). Sikap dan pengetahua Perawat Berhubungan dengan Pelaksanaan Triage. Boyolali: STIKES Estu Utomo.

Santosa ,W.dkk.2015. Hubungan Pengetahuan Perawat Tentang Pemberian Label Triage Dengan Tindakan Perawat Berdasarkan Label Triage. Gresik: Universitas Airlangga.

Sukamto, F.dkk. 2013. Faktor Yang Mempengaruhi Perilaku Perawat Dalam Perawatan Kesehatan. Malang: Universitas Brawijaya 